\title{
Defleksi Lateral Tiang Tunggal Akibat Beban Lateral Pada Tanah Pasir
}

\author{
Ahmad Fahrul Lafit a,*, Togani Cahyadi Upomo ${ }^{\mathrm{b}}$, Yeri Sutopo ${ }^{\mathrm{c}}$, Agung Sutarto ${ }^{\mathrm{d}}$ \\ a,b,c,d Jurusan Teknik Sipil, Fakutas Teknik, Universitas Negeri Semarang, Indonesia
}

Keywords:

lateral deflection

curve $p$-y

plaxis

allpile

Nash-Sutcliffe Efficiency (NSE)

\begin{abstract}
One type of deep foundation is a pile foundation that is designed and has the ability to withstand axial, lateral, and uplift loads. This analysis aims to determine and compare deflections that occur on poles that are in granular soil by using the manual calculation of the p-y curve method with finite difference approaches and calculations with Allpile and Plaxis software. The analysis was conducted three times, namely on a $60 \mathrm{~cm}$ diameter pole at a depth of 10 meters embedded pile with lateral loads of $25 \mathrm{kN}, 50 \mathrm{kN}$, and $75 \mathrm{kN}$. The data used to calculate the lateral deflection of the pole is secondary data. Lateral deflection analysis using Plaxis software with a load of $25 \mathrm{kN}, 50 \mathrm{kN}$, and $75 \mathrm{kN}$ obtained lateral deflection of the uppermost pole respectively $0.159 \mathrm{~cm}, 0.324 \mathrm{~cm}$, and $0.545 \mathrm{~cm}$. Lateral deflection analysis using Allpile software with a load of $25 \mathrm{kN}, 50 \mathrm{kN}$, and $75 \mathrm{kN}$ obtained lateral deflection of the uppermost pile by $0.08 \mathrm{~cm}, 0.16 \mathrm{~cm}$ and $0.29 \mathrm{~cm}$. While the results of the lateral deflection analysis of the manual calculation of the p-y curve method with a finite different up to $25 \mathrm{kN}, 50 \mathrm{kN}$, and 75 $k N$ loads obtained lateral deflection of the uppermost pile respectively by $0.60 \mathrm{~cm}, 0.12 \mathrm{~cm}$ and $0.179 \mathrm{~cm}$. So the approximating calculations are manual calculation of the $p-y$ curve method with calculations with Allpile software. Nash-Sutcliffe Efficiency (NSE) value calculation of the p-y curve method with plaxis software at lateral load $25 \mathrm{kN}, 50 \mathrm{kN}, 75 \mathrm{kN}$ obtained consecutive NSE values of $-5,946,-6,439$, dan $-30,118$ all of which have unsatisfactory performance rating. Different with curve p-y method compared with Allpile that has consecutive NSE values of $0,876,0,876,0,876$, dan 0,605 all of which have very good performance rating.
\end{abstract}

\begin{abstract}
ABSTRAK
Salah satu jenis fondasi dalam adalah fondasi tiang yang didesain dan memiliki kemampuan untuk menahan beban aksial, lateral, dan uplift. Analisis ini bertujuan untuk mengetahui dan membandingkan defleksi yang terjadi pada tiang yang berada pada tanah granuler dengan menggunakan perhitungan manual metode kurva $\mathrm{p}-\mathrm{y}$ dengan pendekatan beda hingga dan perhitungan dengan software Allpile dan Plaxis. Analisis dilakukan tiga kali percobaan yaitu pada tiang berdiameter $60 \mathrm{~cm}$ pada kedalaman tiang tertanam 10 meter dengan beban lateral sebesar $25 \mathrm{kN}, 50 \mathrm{kN}$, dan $75 \mathrm{kN}$. Data yang dipakai untuk menghitung defleksi lateral tiang adalah data sekunder. Analisis defleksi lateral menggunakan software Plaxis dengan beban 25 $\mathrm{kN}, 50 \mathrm{kN}$, dan $75 \mathrm{kN}$ didapatkan defleksi lateral tiang paling atas berturut-turut sebesar 0,159 $\mathrm{cm}, 0,324 \mathrm{~cm}$, dan $0,545 \mathrm{~cm}$. Analisis defleksi lateral menggunakan software Allpile dengan beban $25 \mathrm{kN}, 50 \mathrm{kN}$, dan $75 \mathrm{kN}$ didapatkan defleksi lateral tiang paling atas berturut-turut sebesar $0,08 \mathrm{~cm}, 0,16 \mathrm{~cm}$, dan $0,29 \mathrm{~cm}$. Sedangkan hasil analisis defleksi lateral perhitungan manual metode kurva p-y dengan pendekatan beda hingga dengan beban $25 \mathrm{kN}, 50 \mathrm{kN}$, dan 75 $\mathrm{kN}$ didapatkan defleksi lateral tiang paling atas berturut turut sebesar $0,60 \mathrm{~cm}, 0,12 \mathrm{~cm}$, dan $0,179 \mathrm{~cm}$. Jadi perhitungan yang saling mendekati adalah perhitungan manual metode kurva py dengan perhitungan dengan software Allpile. Perhitungan nilai Nash-Sutcliffe Efficiency (NSE) metode kurva p-y dengan software Plaxis pada beban lateral $25 \mathrm{kN}, 50 \mathrm{kN}$, dan $75 \mathrm{kN}$ didapatkan nilai NSE berturut-turut sebesar $-5,946,-6,493$, dan $-30,118$ yang ketiganya memiliki rating performa tidak memuaskan. Berbeda dengan metode kurva p-y dibanding dengan Allpile memiliki nilai NSE berturut-turut sebesar 0,876, 0,876, dan 0,605 ketiganya mempunyai rating performa yang sangat baik.
\end{abstract}

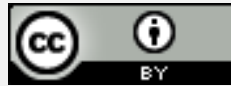

This is an open access article under the CC-BY license. 


\section{Pendahuluan}

Seiring dengan berkembangnya zaman, infrastruktur merupakan bagian penting dari bagian negara. Salah satunya yaitu di negara Indonesia, dimana di Indonesia pembangunan infrastruktur terus ditingkatkan diantaranya berupa jalan, gedung, jembatan, bandara, waduk, dan infrastruktur lainnya. Seperti yang sudah tertuang dalam Peraturan Presiden Republik Indonesia nomor 3 tahun 2016 [1] yang diperbarui dengan Peraturan Presiden Republik Indonesia nomor 58 tahun 2017 tentang percepatan pelaksanaan proyek strategis nasional [2]. Semakin jelas dengan munculnya perpres tersebut bahwa infrastruktur merupakan bagian penting dari berdirinya suatu negara.

Berdiri kokohnya suatu bangunan tidak terlepas dari struktur bawah bangunan yang kokoh juga, biasanya disebut dengan fondasi. fondasi yaitu bangunan struktur yang berada pada susunan paling bawah suatu bangunan yang memiliki fungsi menerima beban dari pile cap atau beban yang berada di atasnya yang kemudian akan diteruskan ke tanah yang berada di bawah fondasi tersebut.

Salah faktor yang menentukan jenis fondasi adalah jenis tanah dimana bangunan akan berdiri. Pada analisis ini pondasi berdiri di atas tanah pasir. Tanah pasir merupakan tanah yang sangat lepas dan tidak padat. Tanah pasir memiliki gradasi butiran yang seragam, kekuatan geser yang rendah karena tidak memiliki daya ikat antar butiran satu sama lainnya dan sulit untuk dipadatkannya sehingga tanah seperti ini butuh perbaikan jika akan dibangun konstruksi di atasnya [3].

Menurut Hardiatmo [4] fondasi adalah bagian terendah dari bangunan yang meneruskan beban bangunan kedalam tanah atau batuan yang berada di bawahnya. Terdapat dua klasifikasi fondasi, yaitu fondasi dangkal dan fondasi dalam (Gambar 1).
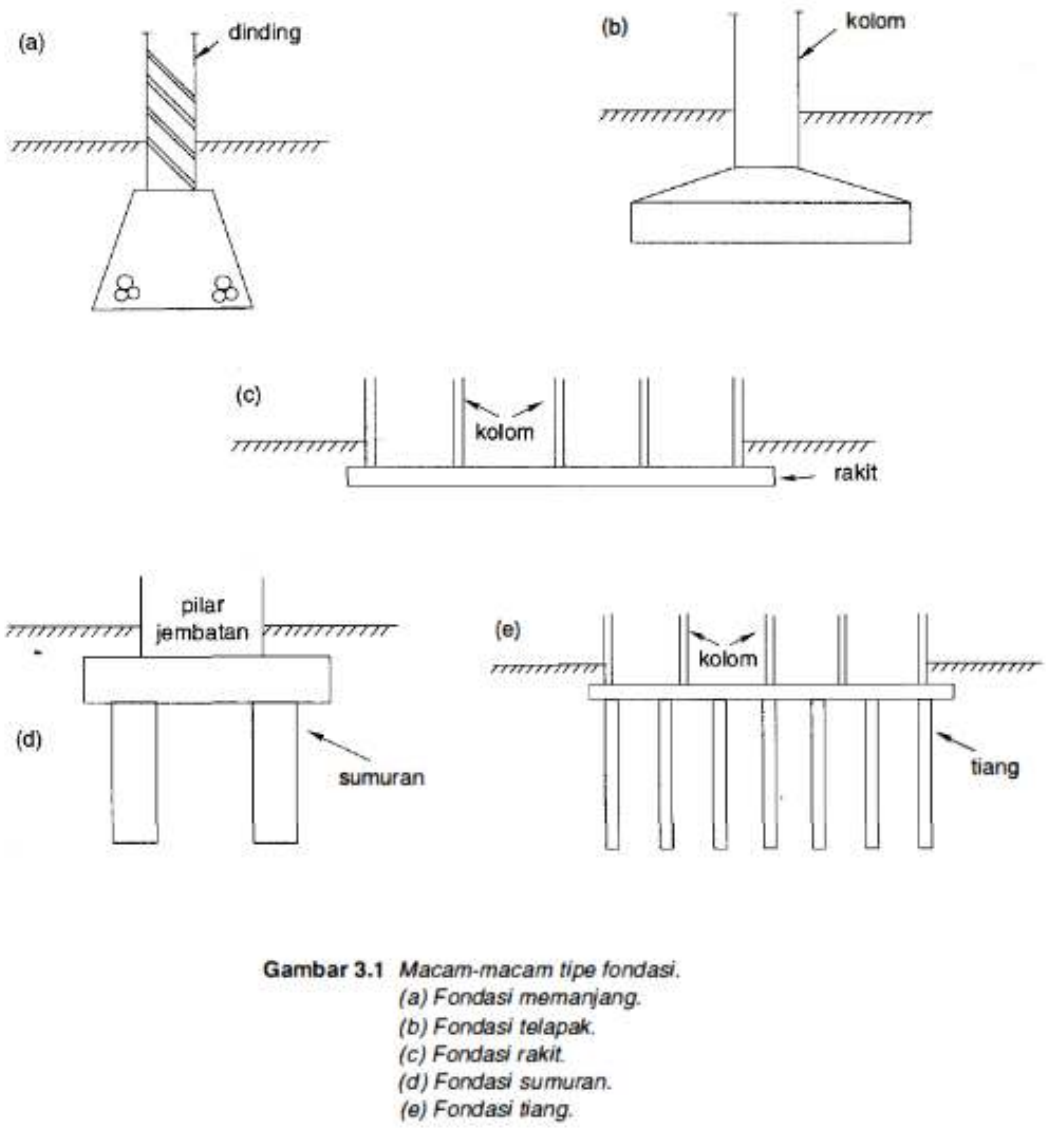

Gambar 1. Jenis-jenis fondasi [4] 
Fondasi dangkal didefinisikan sebagai fondasi yang mendukung bebannya secara langsung, seperti: fondasi telapak, yaitu fondasi yang berdiri sendiri dalam mendukung kolom, fondasi memanjang, yaitu fondasi yang digunakan untuk mendukung dinding memanjang atau digunakan untuk mendukung sederet kolom yang berjarak dekat, sehingga bila dipakai fondasi telapak sisisisinya akan berimpit satu sama lain dan fondasi rakit, yaitu fondasi yang digunakan untuk mendukung bangunan yang terletak pada tanah lunak atau digunakan bila susunan kolom-kolom jaraknya sedemikian dekat di semua arahnya

Fondasi dalam didefinisikan sebagai fondasi yang meneruskan beban bangunan ke tanah keras atau batu yang terletak relatif jauh dari permukaan, contohnya fondasi sumuran, merupakan bentuk peralihan antara fondasi dangkal dan fondasi tiang digunakan bila tanah dasar yang kuat terletak pada kedalaman yang relatif dalam.

Salah satu fondasi dalam yang sering digunakan adalah fondasi tiang pancang karena pelaksanaan cukup mudah dan biaya relatif lebih murah dibandingkan dengan bore pile. Dalam kerangka yang diusulkan oleh [5], fondasi tiang pancang digunakan untuk fondasi suatu bangunan apabila tanah dasar di bawah bangunan tersebut tidak mempunyai daya dukung yang cukup untuk berat bangunan dan bebannya atau apabila tanah keras yang mana yang mempunyai daya dukung yang cukup untuk memikul berat bangunan dan bebannya letaknya sangat dalam. fondasi tiang pancang berfungsi untuk memindahkan atau mentransfer beban dari konstruksi di atasnya kelapisan tanah yang dalam. Menurutnya apabila fondasi tiang pancang diperlukan untuk menahan gayagaya horizontal maka tiang pancang akan dipancangkan miring, sudut kemiringannya tergantung daripada alat pancang serta disesuaikan dengan perencanaannya.

Fondasi tiang pada tanah granuler sudut geser tanah adalah nol, oleh sebab kondisi daya rekat untuk fondasi tiang kurang kuat sehingga ketika di sekitar fondasi terdapat aliran air akan menimbulkan erosi yang akan menggeser kedudukan fondasi tiang.

Fondasi tiang pancang didesain untuk menahan beban axial, lateral, dan uplift. Salah satu faktor penting dalam perencanaan struktur-struktur bangunan tinggi adalah beban lateral. Beban lateral yang bekerja pada tiang pancang mengakibatkan terjadinya defleksi atau pergeseran.

Sebagaimana telah dilaporkan oleh [6], lateral load merupakan gaya yang terjadi pada tiang yang berasal dari berbagai sumber dari sumber tersebut dapat dikategorikan sebagai beban aktif maupun pasif. Beban aktif dianggap bergantung pada waktu atau pembebanan hidup. Beban hidup dapat berasal dari angin, gelombang, arus, es, lalu lintas, tumbukan kapal, dan kekuatan tambatan. Sedangkan beban pasif pada prinsipnya tidak bergantung waktu atau pembebanan pasif. Beban pasif berasal dari tekanan tanah atau tanah yang berpotensi bergerak, tetapi mungkin juga berasal dari pemuatan mati seperti dari jembatan lengkung.

Penentuan kapasitas daya dukung lateral selain memperhitungkan beban lateral, karakteristik tanah dan defleksi lateral yang terjadi juga perlu diperhitungkan. Defleksi maksimum arah lateral yang terjadi tidak boleh melebihi defleksi lateral yang diizinkan. Pada umumnya defleksi lateral yang diizinkan pada fondasi tiang tidak lebih dari $2,50 \mathrm{~cm}[7]$.

Besarnya defleksi lateral yang terjadi pada tiang dapat diketahui dengan melakukan pengujian lapangan atau yang sering disebut dengan lateral test. Selain dengan menggunakan lateral test untuk mengetahui defleksi lateral dapat digunakan juga dengan perhitungan manual Metode Broms 1964 dan metode Kurva p-y, dengan pendekatan Beda Hingga. Selain dengan perhitungan manual defleksi lateral juga dapat di hitung dengan software Allpile dan Plaxis.

Plaxis merupakan salah satu software teknik sipil yang digunakan secara khusus untuk menganalisis deformasi dan stabilitas dalam bidang geoteknik, seperti defleksi lateral dan daya dukung tanah. Kondisi sesungguhnya dapat dimodelkan dalam regangan bidang maupun secara axisymetris. Program ini menerapkan metode antarmuka grafis yang mudah digunakan sehingga pengguna dapat dengan cepat membuat model geometri dan jaring elemen berdasarkan penampang melintang dari kondisi yang ingin dianalisis. Output dari progam ini dapat berupa angka maupun grafik.

Allpile merupakan salah satu software teknik sipil yang digunakan secara khusus untuk menganalisis perilaku 
pondasi dalam bidang geoteknik, seperti defleksi beban lateral dan daya dukung tanah. Penggunaan software Allpile dapat dikategorikan mudah karena pilihan sudah tersedia dengan jelas dan kita hanya menginput data yang dibutuhkan. Output dari progam ini dapat berupa angka maupun grafik.

Metode kurva p-y dengan pendekatan beda hingga merupakan sebuah metode manual untuk mencari defleksi tiang lateral (Gambar 2). Metode ini menggunakan perhitungan berbasis matriks dengan 4 macam persamaan.

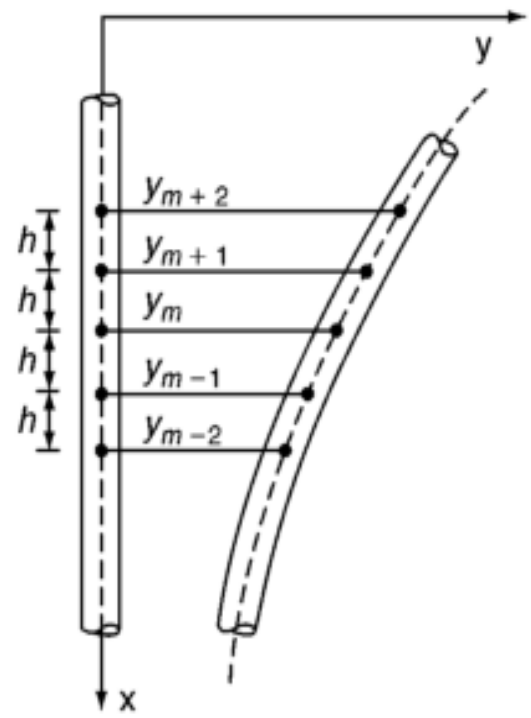

Gambar 2. Defleksi tiang (Single Piles and Pile Groups Under Lateral Loading:33)

Nash-Sutcliffe Efficiency (NSE) merupakan metode yang digunakan untuk memberikan peringkat kinerja dan pedoman standar untuk kriteria efisiensi. Pedoman standar pada rentang nilai dari kriteria efisiensi yang digunakan untuk mengevaluasi kinerja sebuah metode.

\section{Metode}

Perhitungan defleksi lateral tiang tunggal menggunakan 3 metode yaitu perhitungan manual metode kurva $p-y$ dengan pendekatan beda hingga dan perhitungan software Plaxis dan Allpile. Tujuan menggunakan 3 metode dalam perhitungan ini yaitu membandingkan defleksi tiang dengan perhitungan antar metode.

Perhitungan manual metode kurva p-y dengan pendekatan beda hingga mengacu pada buku yang berjudul "Single Piles and Pile Groups Under Lateral
Loading" yang telah diusulkan oleh [6]. Berikut adalah langkah-langkahnya;

Persamaan tiang perkedalaman;

$$
E_{p} . I_{p} \frac{d^{4} y}{d x^{4}}+P_{x} \frac{d^{2} y}{d x^{2}}-p+W=0
$$

Keterangan;

Ep $\quad=$ Modulus elastisitas tiang $\left(\mathrm{kN} / \mathrm{m}^{2}\right)$

Ip $\quad=$ Momen Inersia $\left(\mathrm{m}^{4}\right)$

$\mathrm{P}_{\mathrm{x}} \quad=$ Beban aksial $(\mathrm{kN})$

$\mathrm{p}=$ Reaksi tanah perkedalaman

$\mathrm{W}=$ Beban terdistribusi sepanjang tiang

Modulus elastisitas $\left(\mathrm{kN} / \mathrm{m}^{2}\right)$;

$$
\begin{aligned}
E_{p}= & 4700 \cdot \sqrt{f c^{\prime}} \\
\mathrm{fc}^{\prime} & =\text { Kuat tekan beton }\left(\mathrm{kN} / \mathrm{m}^{2}\right)
\end{aligned}
$$

Momen Inersia $\left(\mathrm{m}^{4}\right)$;

$$
\begin{gathered}
I_{p}=\frac{1}{64} \times 3,14 \times d^{4} \\
\mathrm{~d}=\text { diameter tiang }(\mathrm{m})
\end{gathered}
$$

Tiang yang dipakai merupakan tiang dengan lubang di tengah dan tebal selimut sebesar 0,1 meter maka momen inersia yang dipakai adalah sebagai berikut;

$$
I_{p}=\left(\frac{1}{64} \cdot 3,14 \cdot \mathrm{d}^{4}\right)-\left(\frac{1}{64} \cdot 3,14 \cdot[d-2 \times \mathrm{tb}]^{4}\right)
$$

Kekakuan bending $\left(\mathrm{kN} \cdot \mathrm{m}^{2}\right)$

$$
R_{m}=E_{p} \cdot I_{p}
$$

Dari persamaan tiang per kedalaman tersebut dapat diturunkan menjadi persamaan 6 berikut;

$\mathrm{y}_{\mathrm{m}-2} \cdot \mathrm{R}_{\mathrm{m}-1}+\mathrm{y}_{\mathrm{m}-1} \cdot\left(-2 \mathrm{R}_{\mathrm{m}-1}-2 \mathrm{R}_{\mathrm{m}}+\mathrm{P}_{\mathrm{x}} \mathrm{h}^{2}\right)$

$+\mathrm{y}_{\mathrm{m}}\left(\mathrm{R}_{\mathrm{m}-1}+4 \mathrm{R}_{\mathrm{m}}+\mathrm{R}_{\mathrm{m}-1}-2 \mathrm{P}_{\mathrm{x}} \mathrm{h}^{2}+\mathrm{E}_{\mathrm{pym}} \cdot \mathrm{h}^{4}\right)$

$+y_{m+1} \cdot\left(-2 R_{m}-2 R_{m-1}+P_{x} h^{2}\right)+y_{m+2} \cdot R_{m-1}+W_{m}$. $\mathrm{h}^{4}=0$

keterangan;

$y_{m}=y_{m-n}=y_{m+n}=$ Titik kedalaman tiang yang akan dianalisis

$R_{m}=R_{m-1}=R_{t}=$ Kekakuan bending tiang $\left(\mathrm{kN} \cdot \mathrm{m}^{2}\right)$

$\mathrm{P}_{\mathrm{x}} \quad=$ Beban horisontal $(\mathrm{kN})$

$\mathrm{h}=$ Panjang antar titik seperti pada Gambar 3

$\mathrm{E}_{\mathrm{pym}}=$ Modulus Elastisitas Tanah $\left(\mathrm{kN} / \mathrm{m}^{2}\right)$

Panjang antar titik (m) (Gambar 3)

$\mathrm{h}=\mathrm{L} /(\mathrm{L}+\mathrm{e})$ 
$\mathrm{L}=$ Panjang tiang masuk $(\mathrm{m})$

$\mathrm{e}=$ Panjang Tiang keluar $(\mathrm{m})$

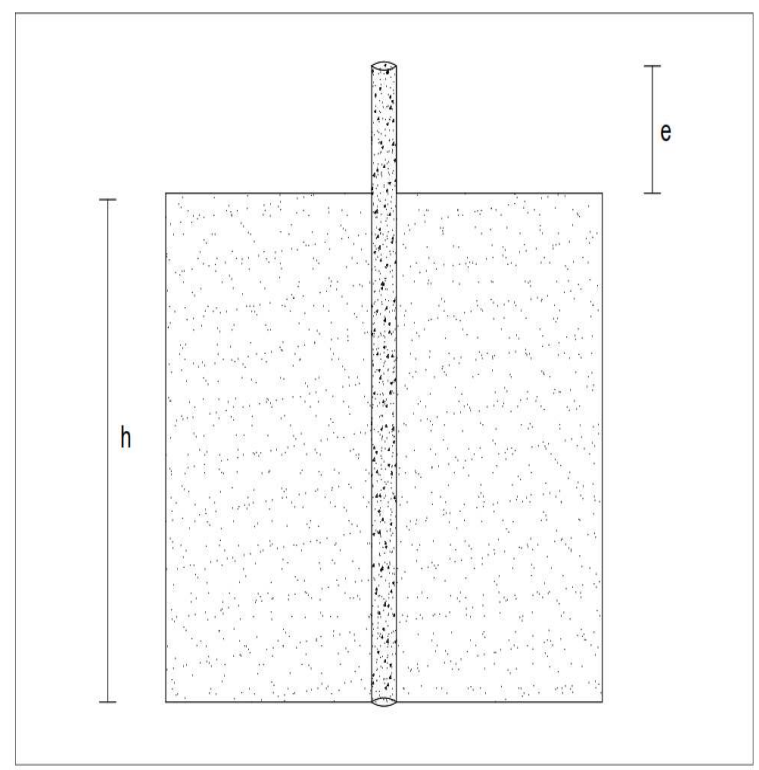

Gambar 3. Panjang antar titik

Kekakuan Bending $\left(\mathrm{kNm}^{2}\right)$

$R_{m}=E_{p} \cdot I_{p}$

$E_{\mathrm{p}}=$ Modulus elastisitas tiang $\left(\mathrm{kN} / \mathrm{m}^{2}\right)$

$\mathrm{I}_{\mathrm{p}}=$ Momen Inersia $\left(\mathrm{m}^{4}\right)$

Modulus Elastisitas Tanah $\left(\mathrm{kN} / \mathrm{m}^{2}\right)$

$\mathrm{E}_{\text {pym }}=500 .(\mathrm{N}-\mathrm{spt}+15)$

$\mathrm{N}$-spt $=$ Nilai spt

Setelah mendapatkan persamaan turunan selanjutnya yaitu menganalisis titik per titik pada Gambar 4 didapatkan persamaan di bawah ini:

Persamaan 7

$\left(\mathrm{y}_{2} \cdot \mathrm{R}_{1}\right)+\mathrm{y}_{1}\left(-2 \mathrm{R}_{1}-2 \mathrm{R}_{-1}+\mathrm{Px}_{\mathrm{x}} \mathrm{h}^{2}\right)$

$+\mathrm{y}_{-1}\left(\mathrm{R}_{1}+4 \mathrm{R}_{-1}+\mathrm{R}_{1}-2 \mathrm{Px} \cdot \mathrm{h}^{2}+\right.$ Epy.h $\left.\mathrm{h}^{4}\right)$

$+y_{-2}\left(-2 R_{-1}-2 R_{-2}+P x \cdot h^{2}\right)+y_{-3} \cdot R_{1}+W_{-1} \cdot h^{4}=0$

Persamaan 8

$\left(\mathrm{y}_{1} \cdot \mathrm{R}_{-1}\right)+\mathrm{y}_{-1}\left(-2 \mathrm{R}_{-1}-2 \mathrm{R}_{-2}+\mathrm{Px}_{2} \mathrm{~h}^{2}\right)$

$+\mathrm{y}_{-2}\left(\mathrm{R}_{-1}+4 \mathrm{R}_{-2}+\mathrm{R}_{-1}-2 \mathrm{Px} \cdot \mathrm{h}^{2}+\mathrm{Epy}^{4} \mathrm{~h}^{4}\right)$

$+y_{-3}\left(-2 R_{-2}-2 R_{-3}+P x \cdot h^{2}\right)+y_{-4} \cdot R_{-1}+W_{-2} \cdot h^{4}=0$

Persamaan 9

$\left(\mathrm{y}_{-1} \cdot \mathrm{R}_{-2}\right)+\mathrm{y}_{-2}\left(-2 \mathrm{R}_{-2}-2 \mathrm{R}_{-3}+\mathrm{Px}^{2} \mathrm{~h}^{2}\right)$

$+\mathrm{y}_{-3}\left(\mathrm{R}_{-2}+4 \mathrm{R}_{-3}+\mathrm{R}_{-2}-2 \mathrm{Px} \cdot \mathrm{h}^{2}+\mathrm{Epy} \cdot \mathrm{h}^{4}\right)$

$+\mathrm{y}_{-4}\left(-2 \mathrm{R}_{-3}-2 \mathrm{R}_{-4}+\mathrm{Px}_{\mathrm{x}} \mathrm{h}^{2}\right)+\mathrm{y}_{-5} \mathrm{R}_{-2}+\mathrm{W}_{-3} \cdot \mathrm{h}^{4}=0$

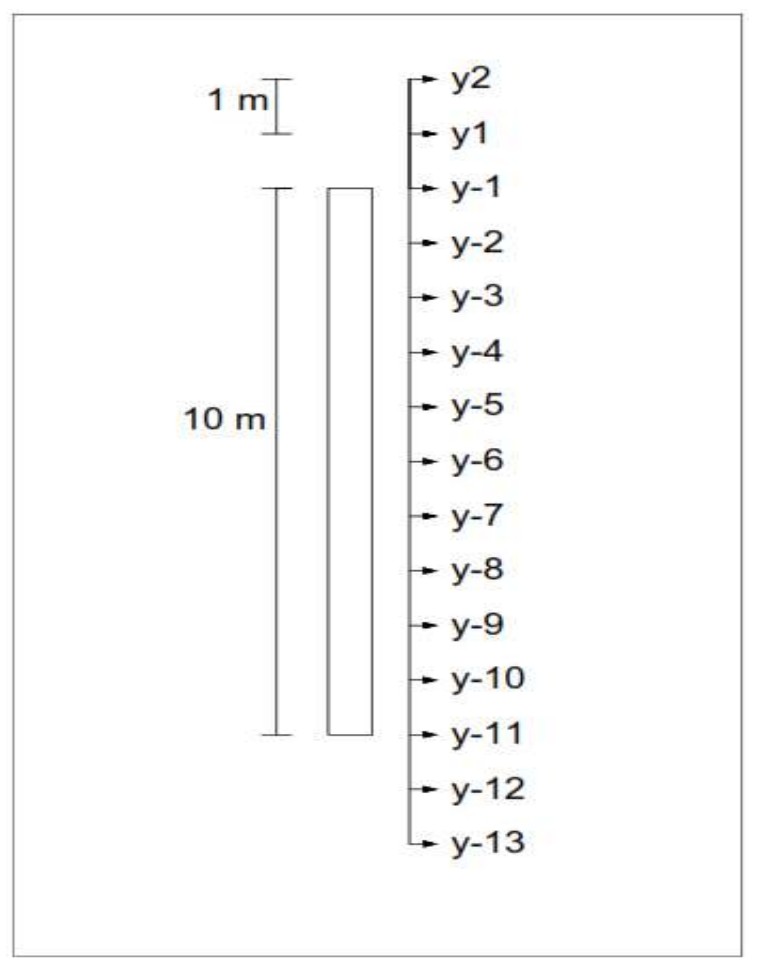

Gambar 4. Titik persamaan yang akan dianalisis

Persamaan 10

$\left(\mathrm{y}_{-2} \cdot \mathrm{R}_{-3}\right)+\mathrm{y}_{-3}\left(-2 \mathrm{R}_{-3}-2 \mathrm{R}_{-4}+\mathrm{Px} \cdot \mathrm{h}^{2}\right)$

$+\mathrm{y}_{-4}\left(\mathrm{R}_{-3}+4 \mathrm{R}_{-4}+\mathrm{R}_{-3}-2 \mathrm{Px} \cdot \mathrm{h}^{2}+\mathrm{Epy} \cdot \mathrm{h}^{4}\right)$

$+\mathrm{y}_{-5}\left(-2 \mathrm{R}_{-4}-2 \mathrm{R}_{-5}+\mathrm{Px}_{\mathrm{x}} \mathrm{h}^{2}\right)+\mathrm{y}_{-6} \cdot \mathrm{R}_{-3}+\mathrm{W}_{-4} \cdot \mathrm{h}^{4}=0$

Persamaan 11

$\left(\mathrm{y}_{-3} \cdot \mathrm{R}_{-4}\right)+\mathrm{y}_{-4}\left(-2 \mathrm{R}_{-4}-2 \mathrm{R}_{-5}+\mathrm{Px}_{\mathrm{x}} \mathrm{h}^{2}\right)$

$+\mathrm{y}_{-5}\left(\mathrm{R}_{-4}+4 \mathrm{R}_{-5}+\mathrm{R}_{-4}-2 \mathrm{Px} \cdot \mathrm{h}^{2}+\mathrm{Epy} \mathrm{h}^{4}\right)$

$+\mathrm{y}_{-6}\left(-2 \mathrm{R}_{-5}-2 \mathrm{R}_{-6}+\mathrm{Px}_{\mathrm{H}} \mathrm{h}^{2}\right)+\mathrm{y}_{-7} \cdot \mathrm{R}_{-4}+\mathrm{W}_{-5} \cdot \mathrm{h}^{4}=0$

Persamaan 12

$\left(\mathrm{y}_{-4} \cdot \mathrm{R}_{-5}\right)+\mathrm{y}_{-5}\left(-2 \mathrm{R}_{-5}-2 \mathrm{R}_{-6}+\mathrm{Px}_{\mathrm{x}} \mathrm{h}^{2}\right)$

$+\mathrm{y}_{-6}\left(\mathrm{R}_{-5}+4 \mathrm{R}_{-6}+\mathrm{R}_{-5}-2 \mathrm{Px} \cdot \mathrm{h}^{2}+\mathrm{Epy}_{\mathrm{H}} \mathrm{h}^{4}\right)$

$+y_{-7}\left(-2 R_{-6}-2 R_{-7}+P_{x} \cdot h^{2}\right)+y_{-8} R_{-5}+W_{-6} \cdot h^{4}=0$

Persamaan 13

$\left(\mathrm{y}_{-5} \cdot \mathrm{R}_{-6}\right)+\mathrm{y}_{-6}\left(-2 \mathrm{R}_{-6}-2 \mathrm{R}_{-7}+\mathrm{Px}^{2} \mathrm{~h}^{2}\right)$

$+\mathrm{y}_{-7}\left(\mathrm{R}_{-6}+4 \mathrm{R}_{-7}+\mathrm{R}_{-6}-2 \mathrm{Px} \cdot \mathrm{h}^{2}+\mathrm{Epy}^{4} \mathrm{~h}^{4}\right)$

$+\mathrm{y}_{-8}\left(-2 \mathrm{R}_{-7}-2 \mathrm{R}_{-8}+\mathrm{Px}_{\mathrm{x}} \mathrm{h}^{2}\right)+\mathrm{y}_{-9} \cdot \mathrm{R}_{-6}+\mathrm{W}_{-7} \cdot \mathrm{h}^{4}=0$

Persamaan 14

$\left(\mathrm{y}_{-6} \cdot \mathrm{R}_{-7}\right)+\mathrm{y}_{-7}\left(-2 \mathrm{R}_{-7}-2 \mathrm{R}_{-8}+\mathrm{Px}_{\mathrm{x}} \mathrm{h}^{2}\right)$

$+\mathrm{y}_{-8}\left(\mathrm{R}_{-7}+4 \mathrm{R}_{-8}+\mathrm{R}_{-7}-2 \mathrm{Px} \cdot \mathrm{h}^{2}+\right.$ Epy.h $\left.^{4}\right)$

$+\mathrm{y}_{-9}\left(-2 \mathrm{R}_{-8}-2 \mathrm{R}_{-9}+\mathrm{Px}_{\mathrm{f}} \mathrm{h}^{2}\right)+\mathrm{y}_{-10 .} \mathrm{R}_{-7}+\mathrm{W}_{-8} \cdot \mathrm{h}^{4}=0$

Persamaan 15

$\left(\mathrm{y}_{-7} \cdot \mathrm{R}_{-8}\right)+\mathrm{y}_{-8}\left(-2 \mathrm{R}_{-8}-2 \mathrm{R}_{-9}+\mathrm{Px}^{2} \mathrm{~h}^{2}\right)$

$+\mathrm{y}_{-9}\left(\mathrm{R}_{-8}+4 \mathrm{R}_{-9}+\mathrm{R}_{-8}-2 \mathrm{Px} \cdot \mathrm{h}^{2}+\mathrm{Epy} \cdot \mathrm{h}^{4}\right)$ 
$+\mathrm{y}_{-10}\left(-2 \mathrm{R}_{-9}-2 \mathrm{R}_{-10}+\mathrm{Px}_{\mathrm{x}} \mathrm{h}^{2}\right)+\mathrm{y}_{-11 \cdot} \mathrm{R}_{-8}+\mathrm{W}_{-9} \cdot \mathrm{h}^{4}=0$

Persamaan 16

$\left(\mathrm{y}_{-8} \cdot \mathrm{R}_{-9}\right)+\mathrm{y}_{-9}\left(-2 \mathrm{R}_{-9}-2 \mathrm{R}_{-10}+\mathrm{Px}^{2} \mathrm{~h}^{2}\right)$

$+\mathrm{y}_{-10}\left(\mathrm{R}_{-9}+4 \mathrm{R}_{-10}+\mathrm{R}_{-9}-2 \mathrm{Px} \cdot \mathrm{h}^{2}+\mathrm{Epy}_{\mathrm{h}} \mathrm{h}^{4}\right)$

$+\mathrm{y}_{-11}\left(-2 \mathrm{R}_{-10}-2 \mathrm{R}_{-11}+\mathrm{Px}_{\mathrm{x}} \mathrm{h}^{2}\right)+\mathrm{y}_{-12 \cdot} \mathrm{R}_{-9}+\mathrm{W}_{-10} \cdot \mathrm{h}^{4}=0$

Persamaan 17

$\left(\mathrm{y}_{-9} \cdot \mathrm{R}_{-10}\right)+\mathrm{y}_{-10}\left(-2 \mathrm{R}_{-10}-2 \mathrm{R}_{-11}+\mathrm{Px}_{\mathrm{x}} \mathrm{h}^{2}\right)$

$+\mathrm{y}_{-11}\left(\mathrm{R}_{-10}+4 \mathrm{R}_{-11}+\mathrm{R}_{-10}-2 \mathrm{Px} \cdot \mathrm{h}^{2}+\right.$ Epy $\left.\mathrm{h}^{4}\right)$

$+\mathrm{y}_{-12}\left(-2 \mathrm{R}_{-11}-2 \mathrm{R}_{-12}+\mathrm{Px}_{\mathrm{x}} \mathrm{h}^{2}\right)+\mathrm{y}_{-13} \cdot \mathrm{R}_{-10}+\mathrm{W}_{-11} \cdot \mathrm{h}^{4}=0$

Persamaan 7 dimasukkan pada matriks pada baris pertama dan kolom pertama, selanjutnya kolom 2 diletakkan mualai dari baris ke dua dan kolom kedua. Begitu seterusnya sampai pada Persamaan 17.

Persamaan ujung bawah tiang pada kondisi batas, merupakan persamaan yang berada ujung paling bawah tiang, misal kedalaman tiang berada $10 \mathrm{~m}$ maka letak persamaan tersebut berada pada kedalaman $10 \mathrm{~m}$. persamaan ujung bawah tiang dianalisis pada kedalaman $10 \mathrm{~m}$ lebih tepatnya yaitu $\mathrm{y}_{11}$ seperti pada gambar 4 . persamaan ujung bawah tiang dimasukkan pada matriks setelah persamaan tiang per kedalaman yaitu berada pada baris ke 18 dan 19 secara berturut-turut berikut adalah persamaannya;

$\mathrm{y}_{-1}-2 \mathrm{y}_{0}+\mathrm{y}_{1}=0$

$\frac{R_{0}}{2 h^{3}}\left(\mathrm{y}_{-2}-2 \mathrm{y}_{-1}+2 \mathrm{y}_{1}-\mathrm{y}_{2}\right)+\frac{P_{x}}{2 h}\left(\mathrm{y}_{-1}-\mathrm{y}_{1}\right)=\mathrm{V}_{0}$

Sehingga menghasilkan persamaan 18 dan 19 di bawah ini;

$1-2+1=0$

$1-2+0+2-1$

Nilai $\mathrm{R}_{0}$ dan $\mathrm{P}_{\mathrm{x}}$ adalah 0 maka maka persamaan menjadi seperti persamaan 19. Jika $\mathrm{y}_{0}$ adalah $\mathrm{y}_{11}$ maka $\mathrm{y}_{-1}$ adalah $\mathrm{y}_{10}$ dan $\mathrm{y}_{-2}$ adalah $\mathrm{y}_{9}$. Jadi persamaan tersebut terletak pada baris ke 12 dan 13, dan pada kolom 10 dan 9 secara berturut-turut. Nilai $\mathrm{V}_{0}$ adalah 0 maka diabaikan.

Persamaan beban lateral $\left(\mathrm{P}_{\mathrm{t}}\right)$ pada kondisi batas, merupakan persamaan beban lateral yang terjadi pada tiang, pada persamaan inilah yang membedakan akibat perbedaan beban lateral. Persamaan ini ditinjau dari kedalaman tiang $0 \mathrm{~m}$ atau pada Gambar 4 berada pada titik $\mathrm{y}_{-1}$ yang mana berarti letak persamaan tersebut dimulai pada kolom $\mathrm{y}_{+2}$ atau kolom pertama. Persamaan $\mathrm{P}_{\mathrm{t}}$ diletakkan di matriks setelah persamaan ujung bawah tiang yaitu pada baris ke 14 . Berikut adalah persamaannya;

$\frac{R_{t}}{2 h^{3}} \cdot\left(\mathrm{y}_{\mathrm{t}-2}-2 \mathrm{y}_{\mathrm{t}-1}+2 \mathrm{y}_{\mathrm{t}+1}-\mathrm{y}_{\mathrm{t}+2}\right)+\frac{P_{x}}{2 h} \cdot\left(\mathrm{y}_{\mathrm{t}-1}-\mathrm{y}_{\mathrm{t}+1}\right)=\mathrm{P}_{\mathrm{t}}$

Sehingga mendapatkan persamaan berikut:

$$
\frac{R_{t}}{2 h^{3}} \cdot\left(\mathrm{y}_{2}-2 \mathrm{y}_{1}+2 \mathrm{y}_{-1}-\mathrm{y}_{-2}\right)=\mathrm{P}_{\mathrm{t}}
$$

Persamaan momen $\left(\mathrm{M}_{\mathrm{t}}\right)$ pada kondisi batas, merupakan persamaan momen yang terjadi pada ujung tiang. Persamaan momen diletakkan setelah persamaan gaya lateral $\mathrm{P}_{\mathrm{t}}$ yaitu berada pada persamaan akhir di baris 15 . Titik tinjau persamaan ini berada pada kedalaman $0 \mathrm{~m}$ meter atau titik $\mathrm{y}_{-1}$ pada gambar 4. Jika titik tinjau berada pada $\mathrm{y}-1$ maka $\mathrm{y}_{\mathrm{t}-1}$ adalah $\mathrm{y}_{1}$ jadi letak persamaan momen ini berada pada baris ke 15 dan dimulai pada kolom 2 atau $\mathrm{y}_{1}$. Berikut adalah persamaannya;

$\frac{R_{t}}{2 h^{3}} \cdot\left(\mathrm{y}_{\mathrm{t}-1}-2 \mathrm{y}_{\mathrm{t}}+2 \mathrm{y}_{\mathrm{t}+1}\right)=\mathrm{M}_{\mathrm{t}}$

Sehingga menghasilkan Persamaan 21 berikut:

$$
\frac{R_{t}}{2 h^{3}} \cdot\left(\mathrm{y}_{1}-2 \mathrm{y}_{-1}+2 \mathrm{y}_{-2}\right)=\mathrm{M}_{\mathrm{t}}
$$

Apabila 4 kategori persamaan yang jika di jumlahkan mempunyai 15 persamaan yaitu;

1. Persamaan tiang per kedalaman mempunyai 11 persamaan

2. Persamaan ujung bawah tiang mempunyai 2 persamaan

3. Persamaan beban lateral $\mathrm{P}_{\mathrm{t}}$ mempunyai 1 persamaan

4. Persamaan momen $M_{t}$ mempunyai 1 persamaan sebagaimana disebutkan sebelumnya.

Langkah selanjutnya yaitu membangun matriks dengan 15 Persamaan tersebut seperti penjelasan pada Gambar 5 di bawah ini: 


\begin{tabular}{|c|c|c|c|c|c|c|c|c|c|c|c|c|c|c|c|c|c|c|}
\hline & & & & & & & & $\mathbf{A}$ & & & & & & & & I & & B \\
\hline & $y-2$ & $\mathrm{y}-1$ & $\mathrm{y}_{1}$ & $\mathrm{y}_{2}$ & $\mathrm{y}_{3}$ & $\mathrm{y}_{4}$ & $\mathrm{y}_{5}$ & $\mathrm{y}_{6}$ & $\mathrm{y}_{7}$ & y8 & y9 & $\mathrm{y}_{10}$ & $\mathrm{y}_{11}$ & $\mathrm{y}_{12}$ & $\mathrm{y}_{13}$ & & & \\
\hline 1 & $\mathrm{x}$ & $\mathrm{x}$ & $\mathrm{x}$ & $\mathrm{x}$ & $\mathrm{x}$ & $\mathrm{x}$ & $\mathrm{x}$ & $\mathrm{x}$ & $\mathrm{x}$ & $\mathrm{x}$ & $\mathrm{x}$ & $\mathrm{x}$ & $\mathrm{x}$ & $\mathrm{x}$ & $\mathrm{x}$ & $y-2$ & & $z$ \\
\hline 2 & $\mathrm{x}$ & $\mathrm{x}$ & $\mathrm{x}$ & $\mathrm{x}$ & $\mathrm{x}$ & $\mathrm{x}$ & $\mathrm{x}$ & $\mathrm{x}$ & $\mathrm{x}$ & $\mathrm{x}$ & $\mathrm{x}$ & $\mathrm{x}$ & $\mathrm{x}$ & $\mathrm{x}$ & $\mathrm{x}$ & $y-1$ & & $z$ \\
\hline 3 & $\mathrm{x}$ & $\mathrm{x}$ & $\mathrm{x}$ & $\mathrm{x}$ & $\mathrm{x}$ & $\mathrm{x}$ & $\mathrm{x}$ & $\mathrm{x}$ & $\mathrm{x}$ & $\mathrm{x}$ & $x$ & $x$ & $\mathrm{x}$ & $\mathrm{x}$ & $\mathrm{x}$ & $\mathrm{y}_{1}$ & & $z$ \\
\hline 4 & $\mathrm{x}$ & $\mathrm{x}$ & $\mathrm{x}$ & $\mathrm{x}$ & $x$ & $\mathrm{x}$ & $\mathrm{x}$ & $\mathrm{x}$ & $\mathrm{x}$ & $\mathrm{x}$ & $\mathrm{x}$ & $\mathrm{x}$ & $\mathrm{x}$ & $\mathrm{x}$ & $\mathrm{x}$ & $\mathrm{y}_{2}$ & & $z$ \\
\hline 5 & $x$ & $x$ & $\mathrm{x}$ & $\mathrm{x}$ & $\mathrm{x}$ & $\mathrm{x}$ & $x$ & $x$ & $x$ & $\mathrm{x}$ & $\mathrm{x}$ & $\mathrm{x}$ & $\mathrm{x}$ & $\mathrm{x}$ & $x$ & $\mathrm{y}_{3}$ & & $z$ \\
\hline 6 & $\mathrm{x}$ & $\mathrm{x}$ & $\mathrm{x}$ & $\mathrm{x}$ & $x$ & $\mathrm{x}$ & $\mathrm{x}$ & $\mathrm{x}$ & $\mathrm{x}$ & $\mathrm{x}$ & $\mathrm{x}$ & $x$ & $\mathrm{x}$ & $\mathrm{x}$ & $x$ & $\mathrm{y}_{4}$ & & $z$ \\
\hline 7 & $\mathrm{x}$ & $\mathrm{x}$ & $\mathrm{x}$ & $x$ & $x$ & $x$ & $\mathrm{x}$ & $\mathrm{x}$ & $\mathrm{x}$ & $\mathrm{x}$ & $x$ & $x$ & $\mathrm{x}$ & $\mathrm{x}$ & $\mathrm{x}$ & $\mathrm{y}_{5}$ & & $z$ \\
\hline 8 & $\mathrm{x}$ & $\mathrm{x}$ & $\mathrm{x}$ & $\mathrm{x}$ & $\mathrm{x}$ & $\mathrm{x}$ & $\mathrm{x}$ & $\mathrm{x}$ & $\mathrm{x}$ & $\mathrm{x}$ & $\mathrm{x}$ & $x$ & $\mathrm{x}$ & $\mathrm{x}$ & $\mathrm{x}$ & $\mathrm{y}_{6}$ & $=$ & $z$ \\
\hline 9 & $\mathrm{x}$ & $\mathrm{x}$ & $\mathrm{x}$ & $\mathrm{x}$ & $\mathrm{x}$ & $\mathrm{x}$ & $\mathrm{x}$ & $\mathrm{x}$ & $\mathrm{x}$ & $\mathrm{x}$ & $\mathrm{x}$ & $\mathrm{x}$ & $\mathrm{x}$ & $\mathrm{x}$ & $\mathrm{x}$ & $\mathrm{y}_{7}$ & & $z$ \\
\hline 10 & $\mathrm{x}$ & $\mathrm{x}$ & $\mathrm{x}$ & $\mathrm{x}$ & $\mathrm{x}$ & $\mathrm{x}$ & $\mathrm{x}$ & $\mathrm{x}$ & $x$ & $\mathrm{x}$ & $x$ & $\mathrm{x}$ & $\mathrm{x}$ & $\mathrm{x}$ & $x$ & $\mathrm{y}_{8}$ & & $z$ \\
\hline 11 & $\mathrm{x}$ & $\mathrm{x}$ & $\mathrm{x}$ & $\mathrm{x}$ & $x$ & $\mathrm{x}$ & $\mathrm{x}$ & $\mathrm{x}$ & $\mathrm{x}$ & $\mathrm{x}$ & $\mathrm{x}$ & $x$ & $\mathrm{x}$ & $\mathrm{x}$ & $\mathrm{x}$ & yg & & $z$ \\
\hline 12 & $x$ & $x$ & $\mathrm{x}$ & $\mathrm{x}$ & $\mathrm{x}$ & $\mathrm{x}$ & $\mathrm{x}$ & $\mathrm{x}$ & $\mathrm{x}$ & $x$ & $x$ & $\mathrm{x}$ & $\mathrm{x}$ & $\mathrm{x}$ & $x$ & $\mathrm{y}_{10}$ & & $z$ \\
\hline 13 & $\mathrm{x}$ & $\mathrm{x}$ & $\mathrm{x}$ & $\mathrm{x}$ & $\mathrm{x}$ & $\mathrm{x}$ & $\mathrm{x}$ & $\mathrm{x}$ & $\mathrm{x}$ & $\mathrm{x}$ & $\mathrm{x}$ & $\mathrm{x}$ & $x$ & $\mathrm{x}$ & $\mathrm{x}$ & $\mathrm{y}_{11}$ & & $z$ \\
\hline 14 & $\mathrm{x}$ & $\mathrm{x}$ & $\mathrm{x}$ & $\mathrm{x}$ & $\mathrm{x}$ & $\mathrm{x}$ & $\mathrm{x}$ & $\mathrm{x}$ & $\mathrm{x}$ & $\mathrm{x}$ & $x$ & $x$ & $\mathrm{x}$ & $\mathrm{x}$ & $\mathrm{x}$ & $\mathrm{y}_{12}$ & & $z$ \\
\hline 15 & $\mathrm{x}$ & $\mathrm{x}$ & $\mathrm{x}$ & $\mathrm{x}$ & $x$ & $x$ & $x$ & $x$ & $\mathrm{x}$ & $\mathrm{x}$ & $x$ & $\mathrm{x}$ & $\mathrm{x}$ & $\mathrm{x}$ & $\mathrm{x}$ & $\mathrm{y}_{13}$ & & $z$ \\
\hline
\end{tabular}

Gambar 5. Matriks untuk perhitungan defleksi lateral

\section{Keterangan:}

Baris ke 1 sampai baris 15 merupakan panjang baris menurut kedalaman tiang yang akan dianalisis.

Baris ke 1 sampai baris 11 diisi dengan persamaan kondisi tiang per kedalaman dan letak urutan kolom menyesuaikan titik yang dianalisis.

Baris 12 dan baris 13 merupakan kondisi batas yang diisi dengan persamaan kondisi ujung bawah pile dan titik tinjau berada pada kedalaman $10 \mathrm{~m}$ atau $\mathrm{y}_{-11}$

Baris ke 14 termasuk kondisi batas diisi dengan persamaan beban lateral $\left(\mathrm{P}_{\mathrm{t}}\right)$, titik tinjau $\mathrm{P}_{\mathrm{t}}$ berada pada kedalaman $0 \mathrm{~m}$ atau $\mathrm{y}_{-1}$

Baris ke 15 masih dalam kondisi batas diisi dengan persamaan momen $\left(\mathrm{M}_{\mathrm{t}}\right)$, titik tinjau $\mathrm{M}_{\mathrm{t}}$ sama dengan titik tinjau $\mathrm{P}_{\mathrm{t}}$.

Perhitungan defleksi dengan software Plaxis dilakukan dengan cara membuat permodelan tiang tertanam dalam tanah, kemudian memasukkan data-data tanah, tiang, dan beban lateral ke dalam parameter yang di tentukan oleh Plaxis. Ada beberapa parameter yang harus dicari dengan perhitungan manual yaitu:

Modulus Young (Es)

$\mathrm{Es}=500(\mathrm{~N}-\mathrm{spt}+15) \mathrm{kN} / \mathrm{m}^{2}$

Poisson ratio

0,3 untuk tanah pasir
Kekakuan lentur (EI)

$\mathrm{EI}=\mathrm{Ep}$. Ip

$E_{p}=4700 \cdot \sqrt{f_{c}^{\prime}}$

$\mathrm{fc}^{\prime}=$ Kuat tekan beton $\left(\mathrm{kN} / \mathrm{m}^{2}\right)$

$I_{p}=\frac{1}{64} \times 3,14 \times d^{4}$

$\mathrm{d}=$ diameter tiang $(\mathrm{m})$

kekakuan normal

$E A=E_{p} .3,14 . r^{2} L$

$\mathrm{r}=$ jari-jari tiang

$\mathrm{L}=$ kedalaman tiang

Setelah input dalam Plaxis dimasukkan semua langkah selanjutnya yaitu melakukan running supaya outputnya dapat diketahui yaitu defleksi tiang.

Sama halnya perhitungan dengan software Plaxis, software Allpile membutuhkan input data namun ada juga parameter yang tidak ada pada data sekunder yang harus dihitung manual, yaitu:

Menurut Nugraha dan Mulyadi [8], Modulus Subgrade horisontal $(\mathrm{K})$

$\mathrm{Ks}=\mu \mathrm{h} . \mathrm{L} / \mathrm{d}$ 
$\mu \mathrm{h}=$ Relative dense untuk tanah pasir keras adalah 34 $\mathrm{MN} / \mathrm{m}^{3}$

$\mathrm{L}=$ Kedalaman yang ditinjau

$\mathrm{d}=$ diameter tiang

Menurut Reese dan Impe [6] nilai $\mathrm{e}_{50}$ tanah pasir adalah 0,8

Input semua data yang dibutuhkan pada Allpile kemudian lakukan running, setelah selesai maka output data akan diketahui yaitu defleksi tiang.

Perhitungan defleksi lateral tiang tunggal menggunakan data sekunder berupa data sondir dan data tanah tes laboratorium. data-data tersebut digunakan untuk menghitung defleksi. Setelah nilai defleksi diketahui semua selanjutnya yaitu mencari koefisien rating peringkat kinerja kriteria efisiensi Nash-Sutcliffe Efficiency (NSE) masing-masing metode yaitu metode kurva $p-y$ dengan Plaxis dan metode kurva $p-y$ dengan Allpile. Berikut persamaan untuk mencari efisiensi kinerja NSE:

$$
\mathrm{E}=1-\frac{\sum_{i=1}^{n}(\mathrm{O} i-\mathrm{Pi})^{2}}{\sum_{i=1}^{n}(\mathrm{O} i-\tilde{\mathrm{O}})^{2}}
$$

keterangan:

$$
\begin{aligned}
\mathrm{E} & =\text { Nilai NSE } \\
\mathrm{O}_{\mathrm{i}} & =\text { Nilai defleksi } \\
\mathrm{P}_{\mathrm{i}} & =\text { Nilai defleksi pembanding } \\
\tilde{\mathrm{O}} & =\text { Rata-rata defleksi }
\end{aligned}
$$

Berikut merupakan tabel rating peringkat kinerja kriteria efisiensi Nash-Sutcliffe Efficiency (NSE)

Tabel 1. Rating peringkat kinerja kriteria efisiensi [9]

\begin{tabular}{ll}
\hline Rating Performa & NSE \\
\hline Sangat Baik & $0,75<\mathrm{NSE}>1$ \\
Baik & $0,65<\mathrm{NSE}>0,75$ \\
Memuaskan & $0,5<\mathrm{NSE}>0,65$ \\
Tidak Memuaskan & $\mathrm{NSE}=<0,5$ \\
\hline
\end{tabular}

\section{Hasil Dan Pembahasan}

Perhitungan dengan menggunakan software Plaxis menghasilkan defleksi lateral pada tiang dengan beban lateral $25 \mathrm{kN}$ adalah sebesar $0.159 \mathrm{~cm}$ pada ujung atas tiang dapat dilihat pada Gambar 6.

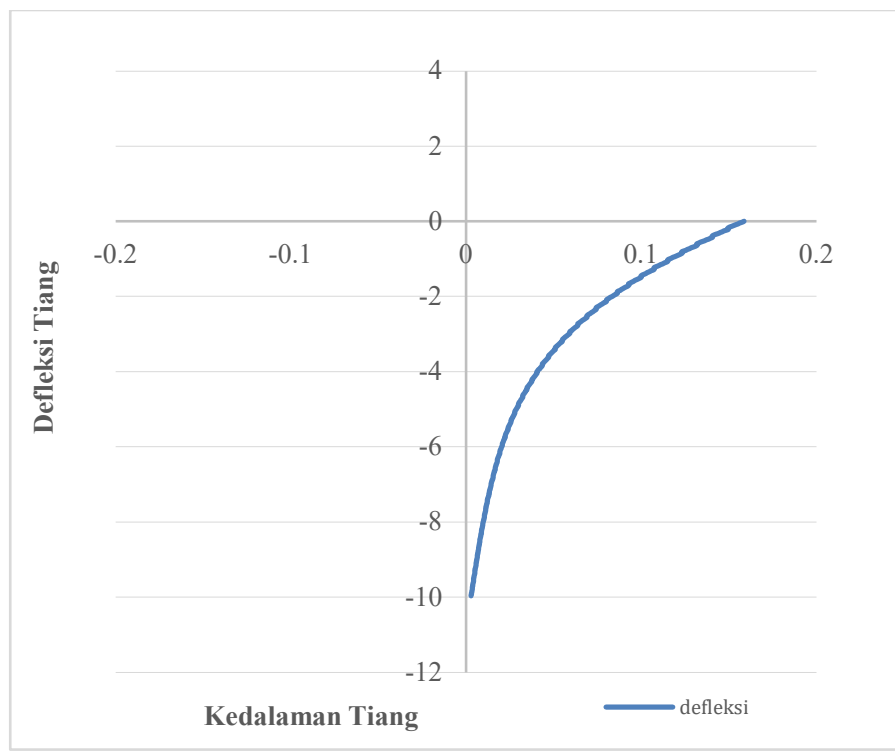

Gambar 6. Grafik defleksi tiang perhitungan software Plaxis dengan beban lateral $25 \mathrm{kN}$

Perhitungan dengan menggunakan software Plaxis menghasilkan defleksi lateral pada tiang dengan beban lateral $50 \mathrm{kN}$ adalah sebesar $0.324 \mathrm{~cm}$ pada ujung atas tiang dapat dilihat pada Gambar 7.

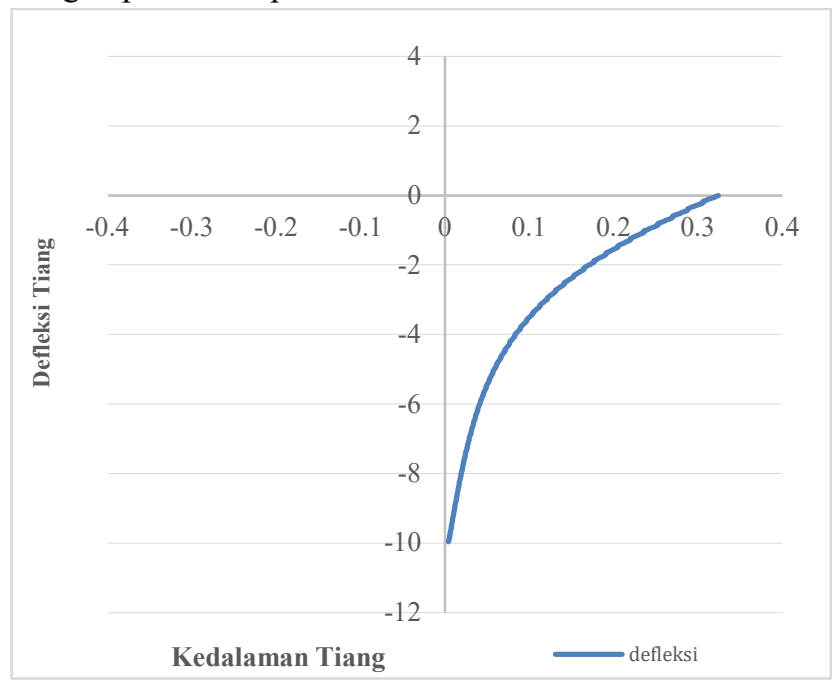

Gambar 7. Grafik defleksi tiang perhitungan software Plaxis dengan beban lateral $50 \mathrm{kN}$

Perhitungan dengan menggunakan software Plaxis menghasilkan defleksi lateral pada tiang dengan beban lateral $75 \mathrm{kN}$ adalah sebesar $0.545 \mathrm{~cm}$ pada ujung atas tiang dapat dilihat pada Gambar 8. 


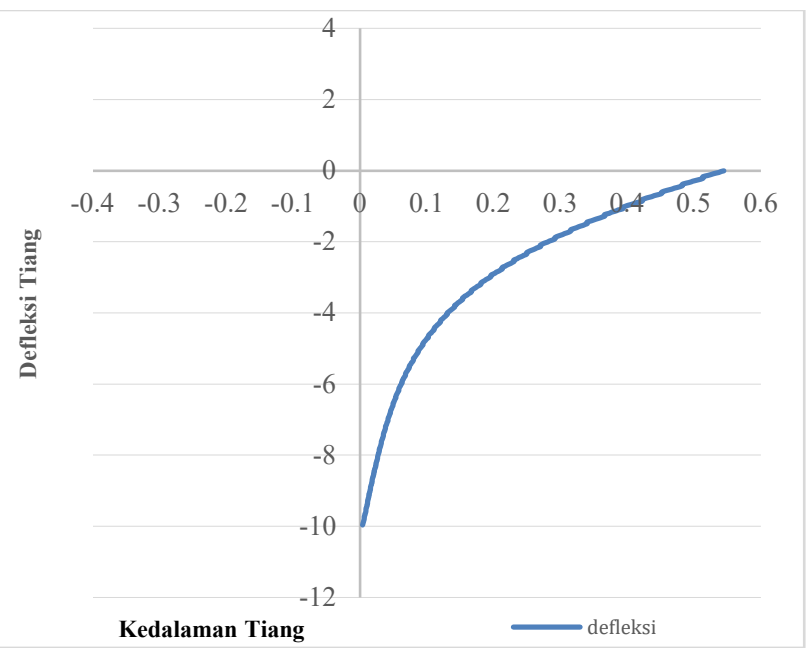

Gambar 8. Grafik defleksi tiang perhitungan software Plaxis dengan beban lateral $75 \mathrm{kN}$

Perhitungan dengan menggunakan software Allpile menghasilkan defleksi lateral pada tiang dengan beban lateral $25 \mathrm{kN}$ adalah sebesar $0.0764 \mathrm{~cm}$ pada ujung atas tiang dapat dilihat pada Gambar 9.

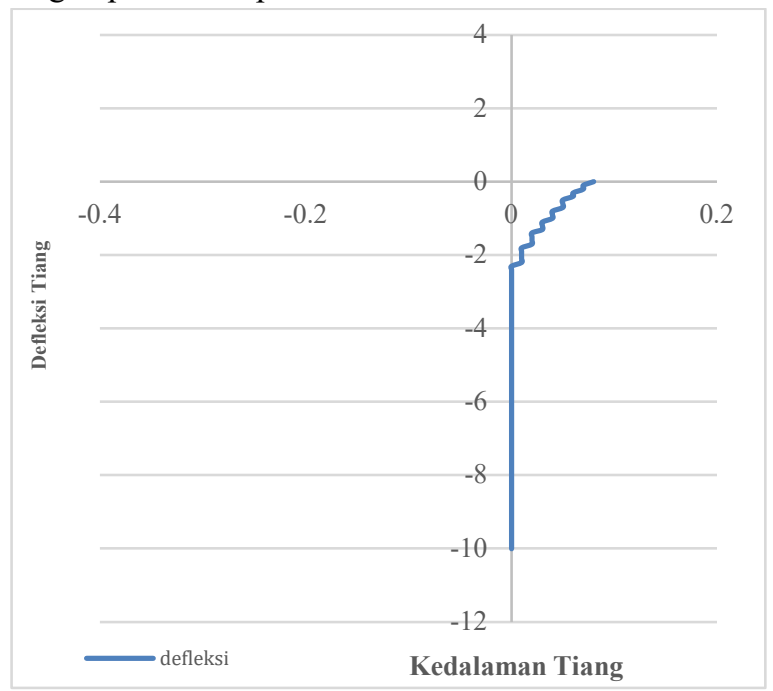

Gambar 9. Grafik defleksi tiang perhitungan software Allpile dengan beban lateral $25 \mathrm{kN}$

Perhitungan dengan menggunakan software Allpile menghasilkan defleksi lateral pada tiang dengan beban lateral $50 \mathrm{kN}$ adalah sebesar $0.161 \mathrm{~cm}$ pada ujung atas tiang dapat dilihat pada Gambar 10.

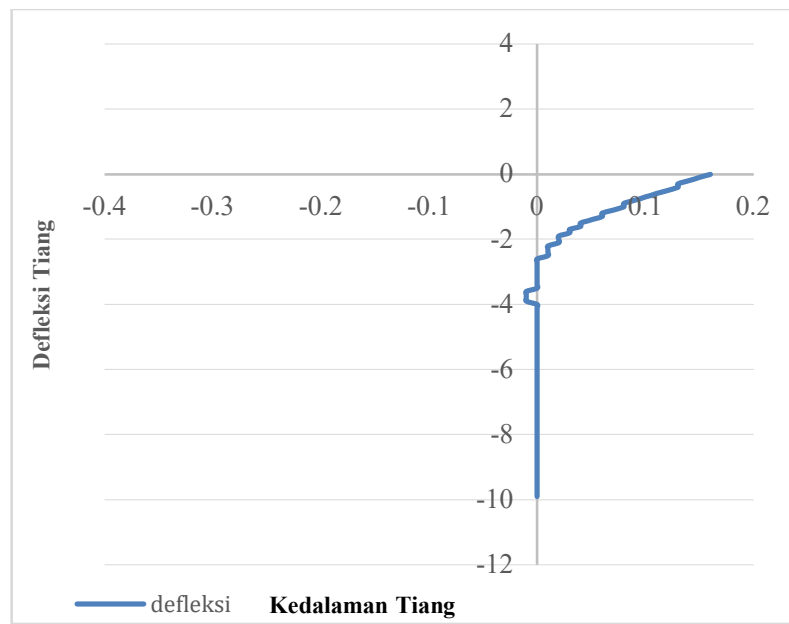

Gambar 10. Grafik defleksi tiang perhitungan software Allpile dengan beban lateral $50 \mathrm{kN}$

Perhitungan dengan menggunakan software Allpile menghasilkan defleksi lateral pada tiang dengan beban lateral $75 \mathrm{kN}$ adalah sebesar $0.289 \mathrm{~cm}$ pada ujung atas tiang dapat dilihat pada Gambar 11.

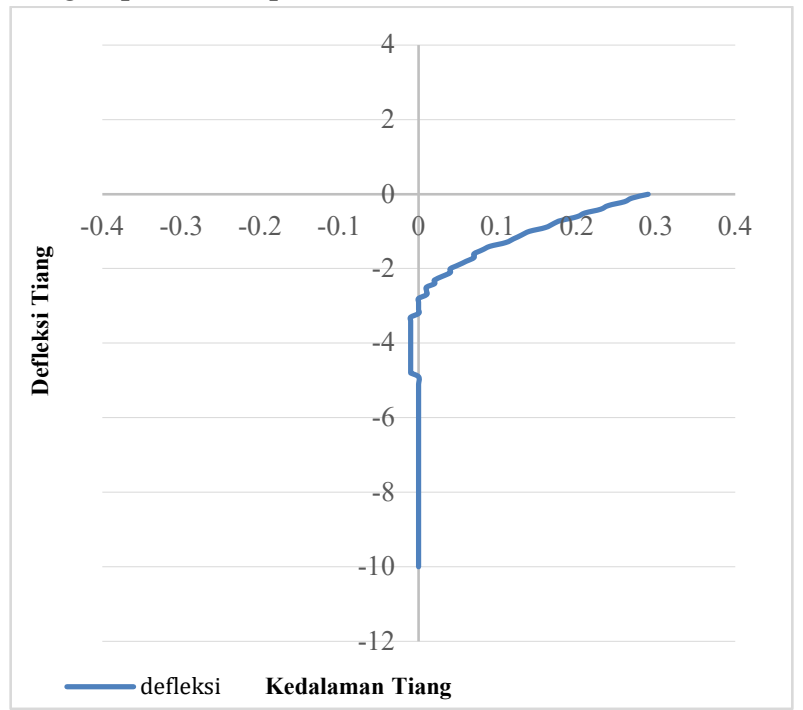

Gambar 11. Grafik defleksi tiang perhitungan software Allpile dengan beban lateral $75 \mathrm{kN}$

Hasil yang didapatkan setelah melakukan perhitungan manual metode kurva p-y dengan pendekatan beda hingga yaitu defleksi lateral tiang paling atas sebesar 0,0597 dengan beban lateral sebesar $25 \mathrm{kN}$. Dapat dilihat pada Gambar 12. 


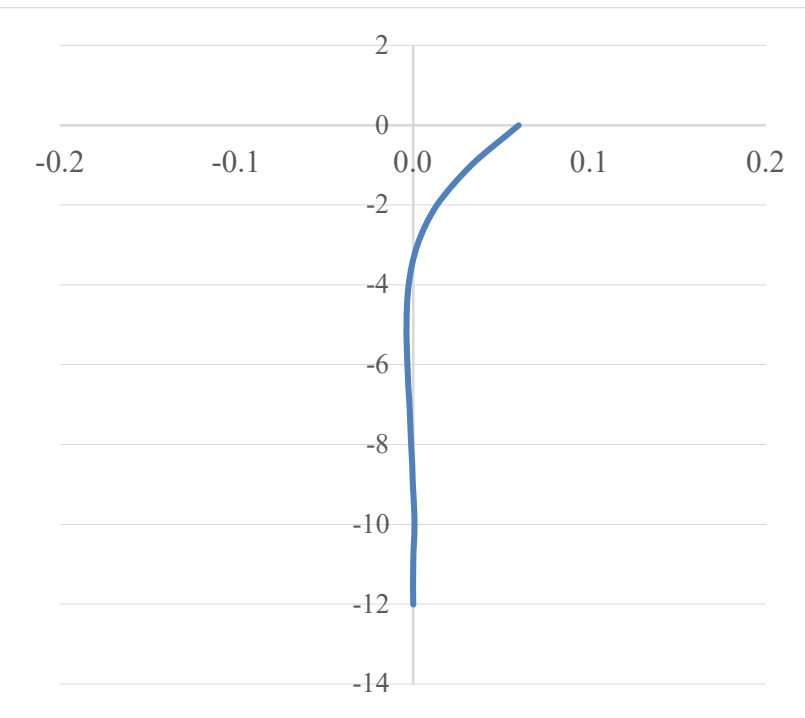

Gambar 12. Grafik defleksi tiang perhitungan metode kurva p-y dengan beban lateral $25 \mathrm{kN}$

Hasil yang didapatkan setelah melakukan perhitungan manual metode kurva $p-y$ dengan pendekatan beda hingga yaitu defleksi lateral tiang paling atas sebesar 0,119 dengan beban lateral sebesar $50 \mathrm{kN}$. Dapat dilihat pada Gambar 13.

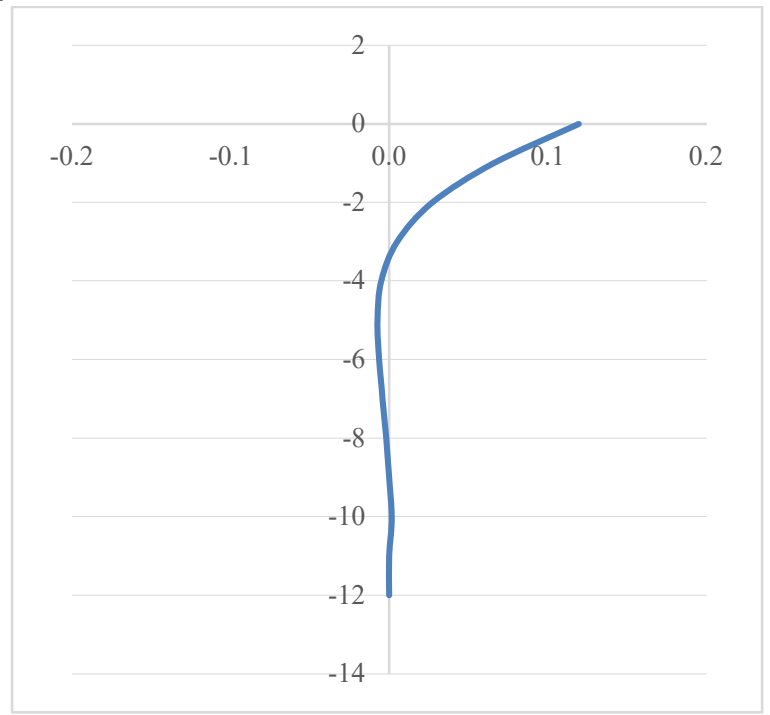

Gambar 13. Grafik defleksi tiang perhitungan metode kurva p-y dengan beban lateral $50 \mathrm{kN}$

Hasil yang didapatkan setelah melakukan perhitungan manual metode kurva p-y dengan pendekatan beda hingga yaitu defleksi lateral tiang paling atas sebesar 0,179 dengan beban lateral sebesar $25 \mathrm{kN}$. Dapat dilihat pada Gambar 14.

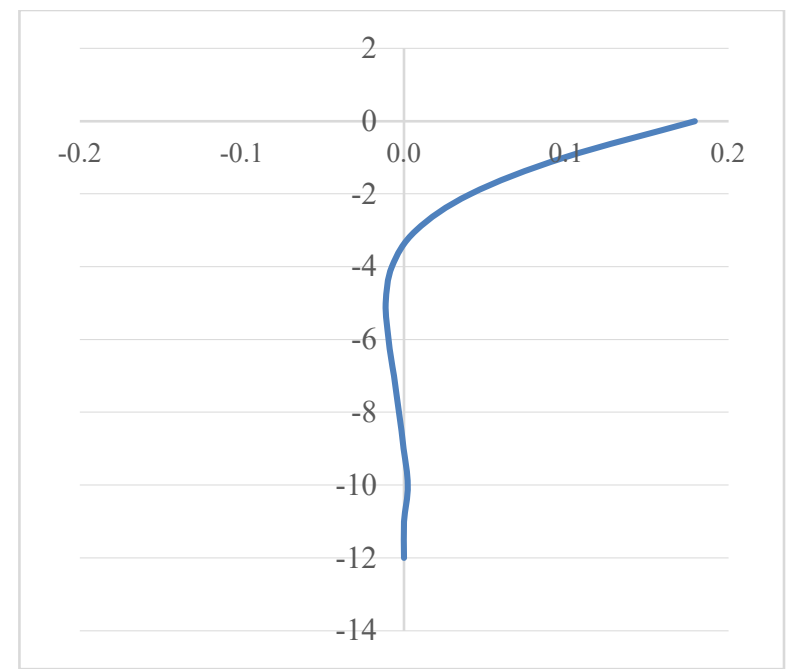

Gambar 14. Grafik defleksi tiang perhitungan metode kurva p-y dengan beban lateral $75 \mathrm{kN}$

Perhitungan defleksi lateral tiang telah dilakukan semua, baik dengan cara perhitungan manual metode kurva p-y ataupun perhitungan dilakukan dengan software plaxis dan Allpile. Masing-masing metode memiliki hasil yang berbeda dan memiliki selisih defleksi yang tidak terlalu signifikan yang dapat dilihat Tabel 2 .

Analisis dilakukan pada kedalaman 0 sampai dengan 10 $\mathrm{m}$, dengan variasi beban sebesar $25 \mathrm{kN}, 50 \mathrm{kN}$ dan $75 \mathrm{kN}$ menggunakan perbandingan software yang berbeda, sebagai pembanding hasil analisis. 
Tabel 2. Perbedaan defleksi hasil perhitungan manual dan software

\begin{tabular}{cccccccccc}
\hline \multirow{2}{*}{$\begin{array}{c}\text { Kedalaman } \\
(\mathrm{m})\end{array}$} & \multicolumn{3}{c}{ Beban 25 kN } & \multicolumn{3}{c}{ Defleksi lateral tiang } \\
\cline { 2 - 9 } & Kurva p-y & Plaxis & Allplile & $\begin{array}{c}\text { Kurva } \\
\text { p0-y }\end{array}$ & Plaxis & Allpile & $\begin{array}{c}\text { Kurva p- } \\
\text { y }\end{array}$ & Plaxis & Allpile \\
\cline { 2 - 10 } & 0,06 & 0,159 & 0,08 & 0,12 & 0,324 & 0,16 & 0,179 & 0,545 & 0,29 \\
-1 & 0,033 & 0,166 & 0,04 & 0,066 & 0,240 & 0,08 & 0,099 & 0,395 & 0,14 \\
-2 & 0,014 & 0,083 & 0,01 & 0,027 & 0,171 & 0,02 & 0,041 & 0,281 & 0,04 \\
-3 & 0,002 & 0,058 & 0 & 0,005 & 0,119 & 0 & 0,007 & 0,194 & 0 \\
-4 & $-0,003$ & 0,040 & 0 & $-0,005$ & 0,082 & $-0,01$ & 0,007 & 0,131 & $-0,01$ \\
-5 & $-0,004$ & 0,028 & 0 & $-0,008$ & 0,058 & 0 & $-0,008$ & 0,890 & 0 \\
-6 & $-0,003$ & 0,020 & 0 & $-0,006$ & 0,041 & 0 & $-0,010$ & 0,062 & 0 \\
-7 & $-0,002$ & 0,014 & 0 & $-0,004$ & 0,029 & 0 & $-0,006$ & 0,042 & 0 \\
-8 & $-0,001$ & 0,010 & 0 & $-0,002$ & 0,0019 & 0 & $-0,003$ & 0,027 & 0 \\
-9 & 0 & 0,006 & 0 & 0 & 0,011 & 0 & 0 & 0,015 & 0 \\
-10 & 0 & 0,003 & 0 & 0,002 & 0,004 & 0 & 0,002 & 0,004 & 0 \\
\hline
\end{tabular}

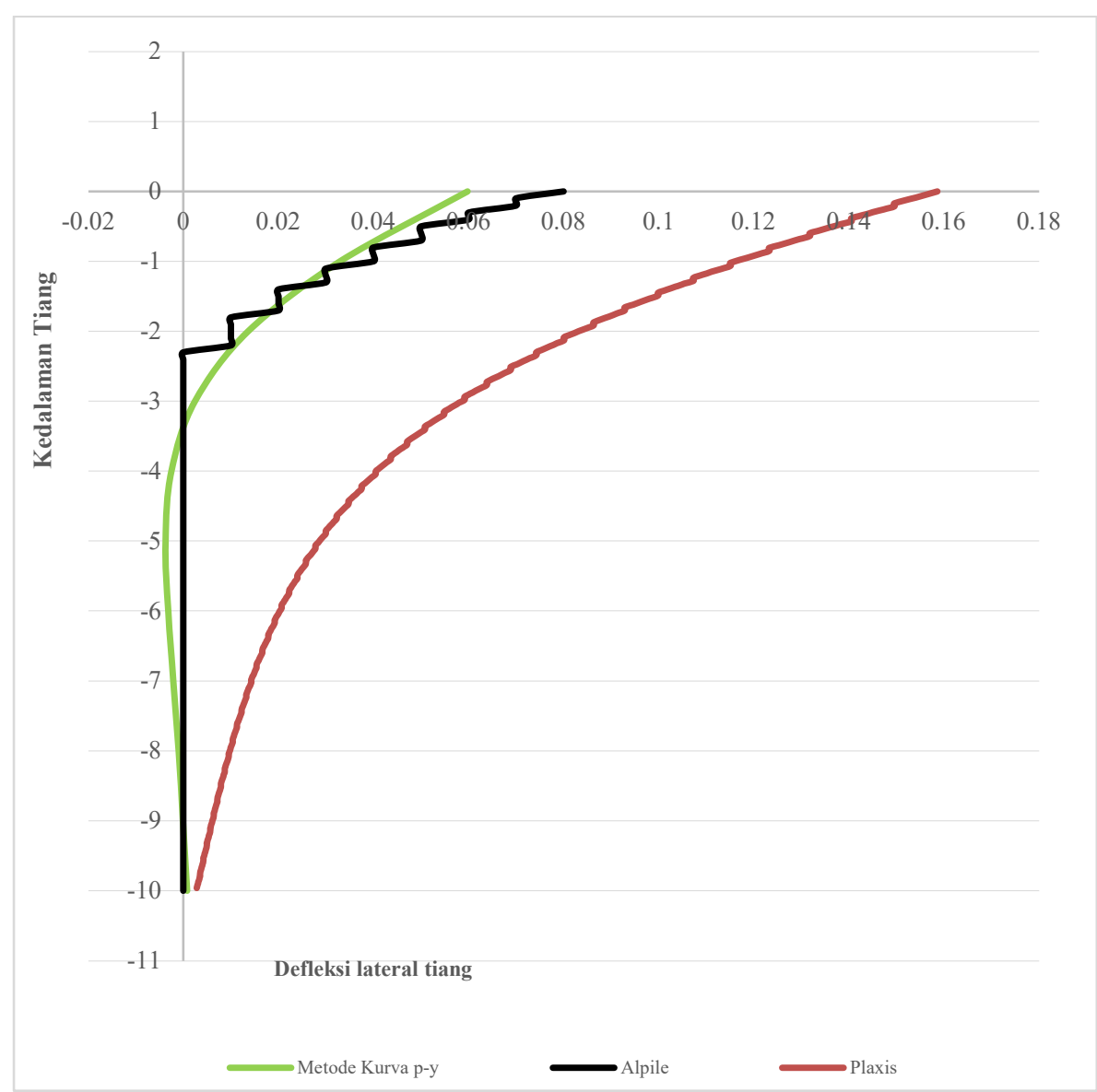

Gambar 15. Grafik perbedaan defleksi antar metode beban $25 \mathrm{kN}$ 


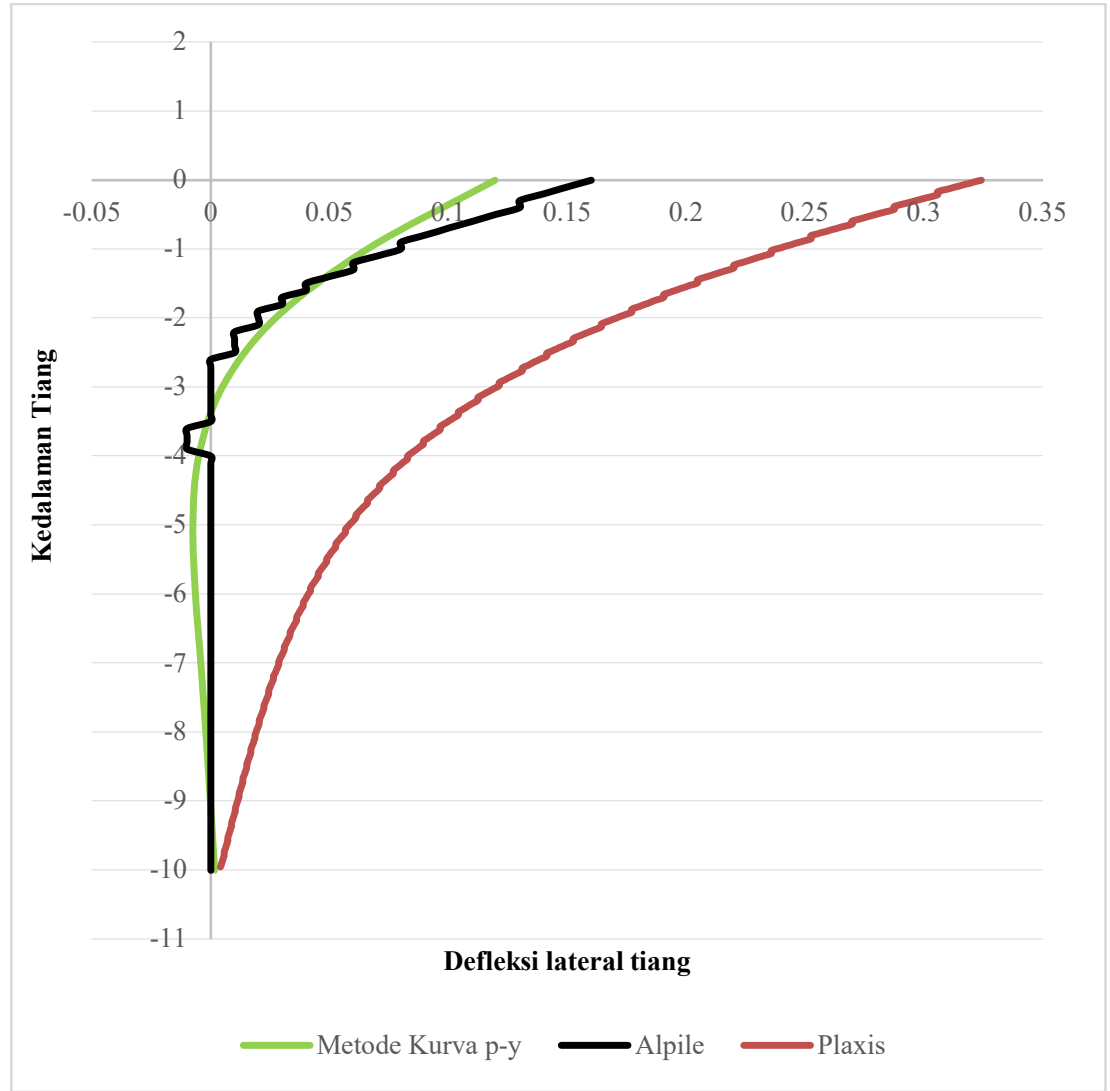

Gambar 16. Grafik perbedaan defleksi antar metode beban $50 \mathrm{kN}$

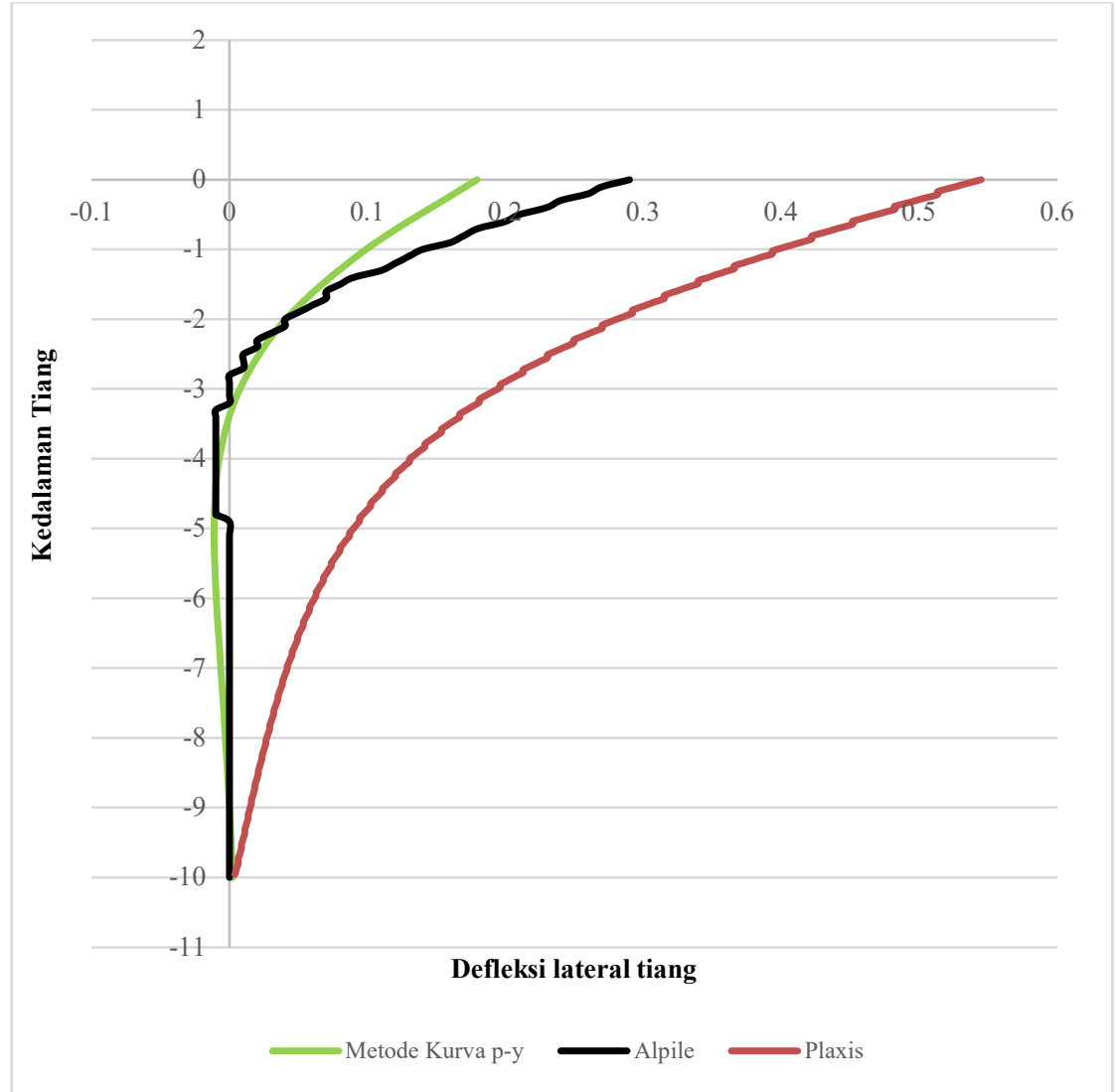

Gambar 17. Grafik perbedaan defleksi antar metode beban $75 \mathrm{kN}$ 
Setelah nilai defleksi diketahui semua selanjutnya yaitu mencari koefisien rating peringkat kinerja kriteria efisiensi Nash-Sutcliffe Efficiency (NSE) masing-masing metode didapatkan sebagai berikut:

Tabel 3. Koefisien Efisiensi kurva p-y dengan Plaxis

\begin{tabular}{|c|c|c|}
\hline Beban & Nilai NSE & Rating \\
\hline $25 \mathrm{kN}$ & $-5,9461$ & $\begin{array}{c}\text { Tidak } \\
\text { memuaskan }\end{array}$ \\
\hline $50 \mathrm{kN}$ & $-6,4936$ & $\begin{array}{c}\text { Tidak } \\
\text { memuaskan }\end{array}$ \\
\hline $75 \mathrm{kN}$ & $-30,118$ & $\begin{array}{c}\text { Tidak } \\
\text { memuaskan }\end{array}$ \\
\hline
\end{tabular}

Tabel 4. Koefisien Efisiensi kurva p-y dengan Allpile

\begin{tabular}{ccc}
\hline Beban & Nilai NSE & Rating \\
\hline $25 \mathrm{kN}$ & 0,8756 & Sangat Baik \\
$50 \mathrm{kN}$ & 0,8754 & Sangat Baik \\
$75 \mathrm{kN}$ & 0,6049 & memuaskan \\
\hline
\end{tabular}

Perhitungan nilai NSE di atas menunjukkan bahwa perhitungan manual kurva $p-y$ dengan pendekatan beda hingga dibandingkan dengan metode software Plaxis tidak di rekomendasikan karena memiliki nilai NSE yang cukup jauh dari standar dan rating perfornya tidak memuaskan. Namun berbeda dengan perhitungan defleksi manual kurva p-y dengan pendekatan beda hingga dibandingkan dengan perhitungan software Allpile, untuk beban lateral kurang dari $75 \mathrm{kN}$ perbandingan keduanya memiliki nilai NSE di atas 0,75 yang berarti rating performanya sangat baik dan direkomendasikan. Tetapi pada beban lateral 75 $\mathrm{kN}$ atau di atasnya kedua metode memiliki Nilai NSE yang rendah atau sebesar 0,6 kisaran angka tersebut memiliki rating performa hanya memuaskan. Jadi tidak disarankan membandingkan untuk beban lateral sebesar $75 \mathrm{kN}$ atau lebih.

\section{Simpulan}

Berdasarkan hasil perhitungan dapat disimpulkan: (1) Perhitungan defleksi lateral menggunakan software Plaxis dengan beban $25 \mathrm{kN}, 50 \mathrm{kN}$, dan $75 \mathrm{kN}$ didapatkan defleksi lateral tiang paling atas berturut-turut sebesar $0,159 \mathrm{~cm}, 0,324 \mathrm{~cm}$, dan $0,545 \mathrm{~cm}$. Perhitungan defleksi lateral menggunakan software Allpile dengan beban 25 $\mathrm{kN}, 50 \mathrm{kN}$, dan $75 \mathrm{kN}$ didapatkan defleksi lateral tiang paling atas berturut-turut sebesar $0,08 \mathrm{~cm}, 0,16 \mathrm{~cm}$, dan $0,29 \mathrm{~cm}$; (2) Perhitungan defleksi lateral tiang secara manual metode kurva p-y dengan pendekatan beda hingga dengan beban $25 \mathrm{kN}, 50 \mathrm{kN}$, dan $75 \mathrm{kN}$ didapatkan defleksi lateral tiang paling atas berturut-turut sebesar $0,60 \mathrm{~cm}, 0,12 \mathrm{~cm}$, dan 0,179 cm; (3) Perhitungan defleksi lateral tiang yang saling mendekati adalah metode kurva p-y dan perhitungan dengan software Allpile; (4)
Perhitungan nilai NSE metode kurva p-y dengan software Plaxis pada beban lateral $25 \mathrm{kN}, 50 \mathrm{kN}$, dan $75 \mathrm{kN}$ didapatkan nilai NSE berturut-turut sebesar -5,946, 6,493 , dan $-30,118$ yang ketiganya memiliki rating performa tidak memuaskan. Berbeda dengan metode kurva p-y dibanding dengan Allpile memiliki nilai NSE berturut-turut sebesar $0,876,0,876$, dan 0,6 yang memiliki rating performa sangat baik.

\section{Daftar Rujukan}

[1] Lembaran Negara Republik Indonesia Tahun 2016 Nomor 4, Peraturan Presiden Republik Indonesia Nomor 3 Tahun 2016. Tentang Percepatan Pelaksanaan Proyek Strategis Nasional. 12 Januari 2016. 2016.

[2] Lembaran Negara Republik Indonesia Tahun 2017 Nomor 119, Peraturan Presiden Republik Indonesia Nomor 58 Tahun 2017. Perubahan Atas Peraturan Presiden nomor 3 Tahun 2016 Tentang Percepatan Pelaksanaan Proyek Strategis Nasional. 2017.

[3] A. Hakam, R. Yuliet, and R. Donal, "Studi pengaruh penambahan tanah lempung pada tanah pasir pantai terhadap kekuatan geser tanah," Junal Rekayasa Sipil, vol. 6, no. 1, p. 11, 2010.

[4] H. C. Hardiyatmo, Teknik Fondasi 1. Jakarta: PT Gramedia Pustaka Utama, 1996.

[5] S. HS, Pondasi Tiang Pancang, 1st ed. Surabaya: Sinar Wijaya, 1988.

[6] L. C. Reese and W. V. Impe, Single Piles and Pile Groups Under Lateral Loading, 2nd ed. Leiden: CRC Press/Balkema, 2010.

[7] F. M. Elfaaz and I. N. Hamdhan, "Analisis Daya Dukung Lateral Fondasi Tiang Tunggal Menggunakan Metode Elemen Hingga," J. Online Inst. Teknol. Nas., vol. 2, no. 3, pp. 83-94, 2016. 